\title{
ガラス繊維強化プラスチックの室温・低温での引張圧縮 およびせん断に対する力学的特性
}

\author{
神谷 大揮*, 池上 皓三**
}

(1994 年 4 月 20 日受付)

\author{
Mechanical Properties of Glass Reinforced Epoxy Resin \\ for Tensile, Compressive and Shear Load at \\ Room Temperature and at Low Temperature \\ Daiki KamiYA* and Kozo IKEgami** \\ (Received April 20, 1994)
}

\begin{abstract}
Mechanical properties of glass fiber reinforced plastics of epoxy resin is experimentally investigated at $77 \mathrm{~K}$ and at room temperature. Tensile or shear load is applied to a cylindrical specimen, and the stress strain curves and the fracture stresses are determined. The compressive tests are conducted by using plate specimen. Elastic constants and fracture stresses of the unidirectionally reinforced plastics at $77 \mathrm{~K}$ are larger than those at room temperature. The deformation behavior shows more linearity at $77 \mathrm{~K}$ than at room temperature. When shear load is applied to the laminated specimens with symmetric cross ply, brittle fracture occurs at $77 \mathrm{~K}$ by delaminations and cracks in directions parallel to the fiber and plastic deforamtion occurs at room temperature. When tensile load is applied to laminated specimens with symmetric angle ply, the fracture stresses at $77 \mathrm{~K}$ are larger than those at room temperature except for the specimen with ply angle of 45 degree. For ply angle of 45 degree the fracture stresses at $77 \mathrm{~K}$ are smaller than that at room temperature. As to the fracture mode, the cracking parallel to the fiber is dominant for large ply angle.
\end{abstract}

1. 緒

近年の宇宙開発技術や超伝導応用技術の発展にともな い, 繊維強化プラスチックが低温での構造材料として用 いられる機会が増えており，低温での繊維強化プラスチ ックの力学的特性の必要が高まってきている.

従来, 低温での繊維強化プラスチックの力学的特性に 対して, 例えば, 引張負荷に対する応力ひずみ関係 ${ }^{1)}$, 負 荷速度や切欠形状が引張強さにおよぼす影響2), 引張と 曲げに対する強さ ${ }^{3)}$, 引張強さと疲れ強さ4), 疲れ強さと 材料構成の関係5), 層間の強さ, 引張強さ, 疲れ強さ ${ }^{6)}$, 引張強さや疲れ強さにおよぼす吸水効果の影響7, 引張

\footnotetext{
*,** 東京工業大学精密工学研究所 (227 横浜市緑区長 津田町 4259)

Precision and Intelligence Laboratory, Tokyo Institute of Technology, 4259, Nagatsuta, Midoriku, Yokohama 227, Japan

* 大学院生 Graduate Student, ${ }^{* *}$ 教授 Professor
}

破壊䩲性 ${ }^{8)}$, 曲げ強さの異方性 ${ }^{9)}$ が研究されている。これ らはほとんど単一の負荷を対象を行ったものであり，同 一の材料で負荷の種類を変えてその力学的特性を調べた 例はほとんどない.

そこで本研究では, ガラス纎維強化エポキシ樹脂の薄 肉円筒試験片に引張圧縮, ねじりの負荷を加え, 液体窒 素温度 $(77 \mathrm{~K})$ での一方向強化材の引張圧縮およびせん 断の変形と強度特性, また対称斜交積層材の引張とせん 断の変形と強度特性を実験により調べた。これらの結果 を室温での力学的特性と比較することにより, $77 \mathrm{~K}$ と室 温での力学的特性の違いを明らかにした。

\section{2. 実験}

\section{1 試験片と試験機}

Fig. 1 に実験に用いた試験片の形状と寸法を示す.試 験片は, ガラス繊維強化プラスチックの薄肉円筒試験片 (以下，GFRP 円筒試験片と呼ぶ)である. 試験片の材料 は長繊維一方向プリプレグ(化成コンポジット製 


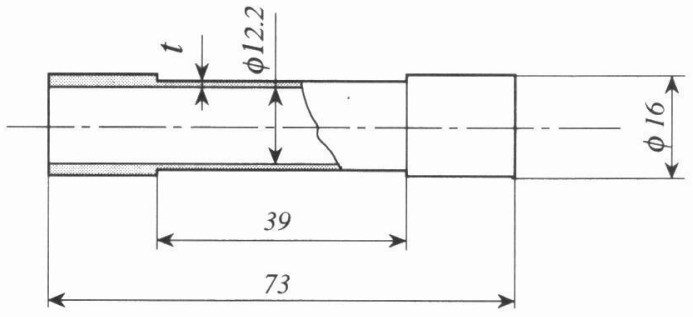

Fig. 1 GFRP cylindrical specimen.

HyE 90714 AF) を使用した。強化繊維は E ガラス (日東 紡製 RF 110 QL-533)で, マトリックスは熱硬化性エポキ シ樹脂(化成コンポジット製 $7714 \mathrm{~A}$ )である.試験片のゲ ージ部の肉厚 $t$ は実験内容により積層枚数によって変化 する。

実験に用いた試験片の肉厚 $t$ は $0.35 \mathrm{~mm}$ から 1.2 mm である. GFRP 円筒試験片は, 離型剤を塗布したス テンレス製マンドレルに裁断したプリプレグを積層し， その上から熱に反応し収縮するテープを巻き付け，巻き 付け時の予張力とテープの収縮に伴い生じる圧力により 成型した。硬化条件は電気炉中において $85^{\circ} \mathrm{C} て ゙ 40$ 分 間, その後 $120^{\circ} \mathrm{C} て ゙ 120$ 分間である. 硬化後, 炉内で約 3 時間で室温まで温度を下げる。熱収縮テープを取り除
き，GFRP 円筒試験片のつかみ部を製作する，試験片の 繊維含有率は約 40〜 50\%であり, 繊維の配向が円周方向 であるとき $40 \%$ ，軸方向であるとき $50 \%$ である。

試験装置とその制御装置の構成を Fig. 2 に示す. 負荷 形式は電気油圧サーボ系を採用している. 試験機の二重 円筒管の内外円筒のそれぞれに GFRP 円筒試験片の端 部が取付けられ，この二重円筒管の上部と下部に位置す る2 個のアクチュエータにより，軸方向とねじり方向の 二種類の荷重を負荷することができる10). 試験温度は試 験片取付治具につけられた熱電対で確認した。実験は試 験装置のロードセルにより測定された負荷荷重をフィー ドバック信号として，応力制御で行った。

\section{2 試験 方 法}

試験片にかかる負荷はロードセルにより測定された值 と試験片形状から計算した。負荷速度は負荷開始から最 終破断までほほ 10 分間となるようにした。これは負荷 速度を一定にすると繊維方向によって強さが大きい場合 には実験が長時間になること，また低温では脆性的にな るので, 負荷速度の影響が小さいと考えたためである. 試験片のひずみは，試験片のゲージ部にはり付けたひず

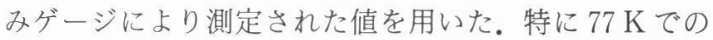
実験には低温用ひずみゲージを用いた。この GFRP 円筒 試験片を用いて行った実験を以下に示す。

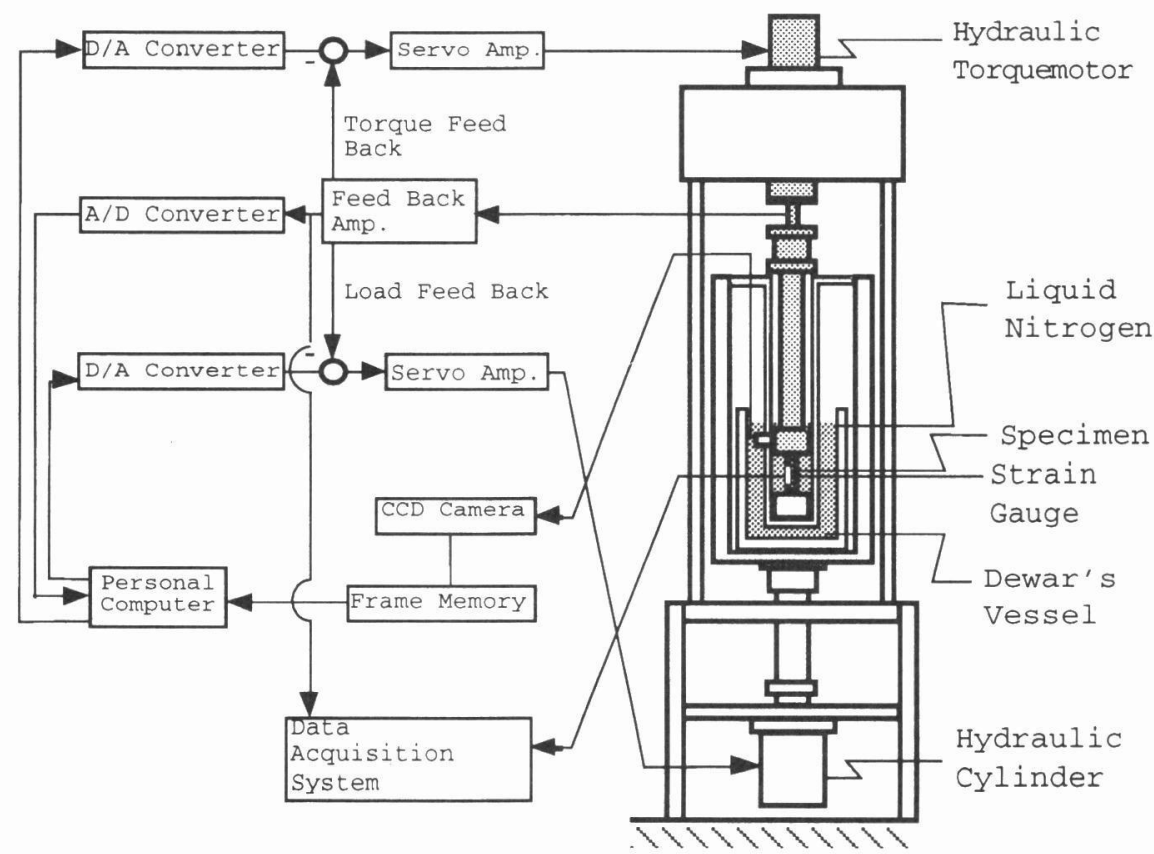

Fig. 2 Schematic drawing of combined loading machine for low temperature. 
(1) 一方向強化材の繊維方向への引張(ガラス繊維を 円筒の軸方向に配向).

(2) 一方向強化材の繊維に垂直方向への引張 (ガラス 瀻維を円周方向に配向).

(3) 一方向強化材のねじり(ガラス繊維を軸方向に配 向).

（4）対称斜交積層材の対称軸方向への引張。ガラス繊 維を軸方向に対して $[+\theta /-\theta /-\theta /+\theta]$ で配向させた。 $\theta$ は $15^{\circ}, 30^{\circ}, 45^{\circ}, 60^{\circ}$ とした.

（5）対称直交積層材のねじり。ガラス繊維を軸方向に 対して $\left[0^{\circ} / 90^{\circ} / 90^{\circ} / 0^{\circ}\right]$ で配向させた。

GFRP 円筒試験片では，座屈などにより圧縮特性を正 確に求めることが困難である。そのため，一方向強化材 の圧縮特性を調べるために GFRP 圧縮試験片をもちい た. Fig. 3 に板形状のガラス繊維強化エポキシ樹脂圧縮 試験片 (以下，GFRP 圧縮試験片と呼ぶ)の形状と寸法を 示す。試験片材料にはGFRP 円筒試験片と同じプリプ レグを用いた。以下の手順で GFRP 圧縮試験片を製作

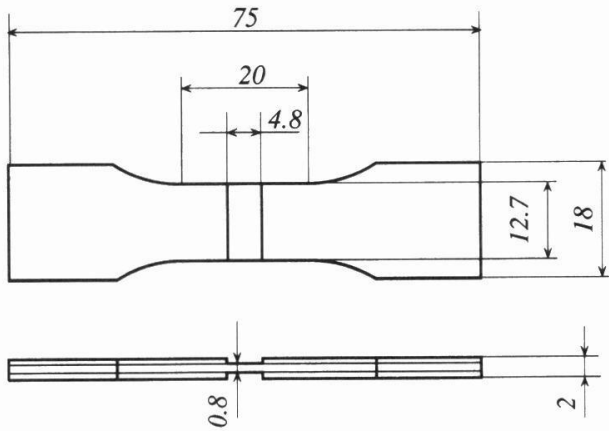

Fig. 3 Dimensions of GFRP compressive test specimen.

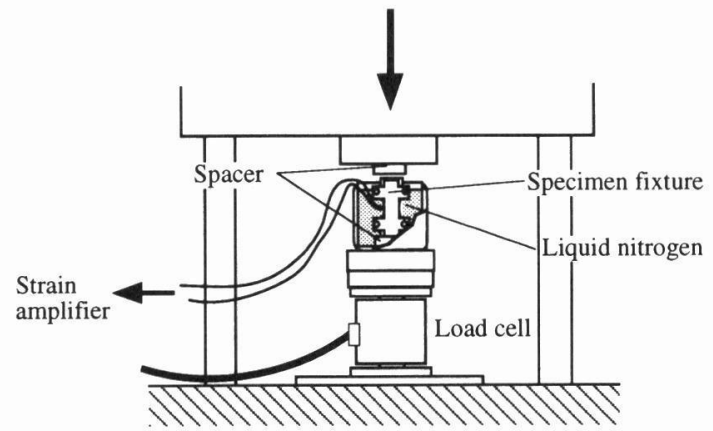

Fig. 4 Schematic drawing of compressive testing method.
した、プリプレグを $100 \mathrm{~mm} \times 20 \mathrm{~mm}$ に裁断し 8 積層さ せる、積層したものを型に入れて圧力をかけながら，熱 硬化させる。硬化条件はGFRP 円筒試験片の場合と同 じである．硬化後フライス盤で矩形に仕上げる．タブ部 分をエポキシ接着剤で接着する。接着剤が硬化した後 に，フライス盤で目的の寸法に仕上げる.

Fig. 4 に圧縮実験の方法を示す.製作したGFRP 圧縮 試験片を座屈防止治具に挟み，万能試験機により圧縮荷 重を負荷して実験を行った。このGFRP 圧縮試験片を用 いて, 一方向強化材の繊維方向と繊維に垂直方向の圧縮 特性の測定を行った。

\section{3. 一方向強化材の基本的力学的特性}

\section{1 織維方向の特性}

Table 1 と Table 2 に実験より得られた $77 \mathrm{~K}$ と室温

Table 1 Experimental fracture stress of GFRP specimen at $77 \mathrm{~K}$ and at room temperature.

\begin{tabular}{lccc}
\hline \hline & & $\begin{array}{c}77 \mathrm{~K} \\
{[\mathrm{MPa}]}\end{array}$ & $\begin{array}{c}\text { Room } \\
\text { temp. } \\
{[\mathrm{MPa}]}\end{array}$ \\
\hline $\begin{array}{l}\text { Tensile strength of } \\
\text { fiber direction }\end{array}$ & $F_{1 \mathrm{t}}$ & 1,150 & 899 \\
$\begin{array}{l}\text { Compressive strength } \\
\text { of fiber direction }\end{array}$ & $F_{1 \mathrm{c}}$ & 817 & 694 \\
$\begin{array}{l}\text { Tensile strength of } \\
\text { transverse direction }\end{array}$ & $F_{2 \mathrm{t}}$ & 32.3 & 25.2 \\
$\begin{array}{l}\text { Compressive strength } \\
\text { of transverse direction }\end{array}$ & $F_{2 \mathrm{c}}$ & 235 & 98.0 \\
$\begin{array}{l}\text { Shear strength in } \\
\text { reinforced plane }\end{array}$ & $F_{12}$ & 76.9 & 47.9 \\
\hline
\end{tabular}

Table 2 Elastic constants of GFRP at $77 \mathrm{~K}$ and at room temperature.

\begin{tabular}{|c|c|c|c|}
\hline & & $77 \mathrm{~K}$ & $\begin{array}{l}\text { Room } \\
\text { temp. }\end{array}$ \\
\hline $\begin{array}{l}\text { Young's modulus of } \\
\text { fiber direction }\end{array}$ & $E_{1}$ & $\begin{array}{l}40.2 \mathrm{GPa} \\
\quad(40.2)\end{array}$ & $\begin{array}{c}38.9 \mathrm{GPa} \\
(33.7)\end{array}$ \\
\hline $\begin{array}{l}\text { Young's modulus of } \\
\text { transverse direction }\end{array}$ & $E_{2}$ & $\begin{array}{l}16.0 \mathrm{GPa} \\
(16.0)\end{array}$ & $\begin{array}{c}10.6 \mathrm{GPa} \\
(8.35)\end{array}$ \\
\hline Shearing modulus & $G_{12}$ & $\begin{array}{c}5.49 \mathrm{GPa} \\
(4.77)\end{array}$ & $\begin{array}{c}3.32 \mathrm{GPa} \\
(1.29)\end{array}$ \\
\hline Poisson's ratio & $\nu_{12}$ & 0.31 & 0.32 \\
\hline Poisson's ratio & $\nu_{21}$ & 0.23 & 0.13 \\
\hline
\end{tabular}

( ) : Elastic constants defined by fracture stress and fracture strain. 


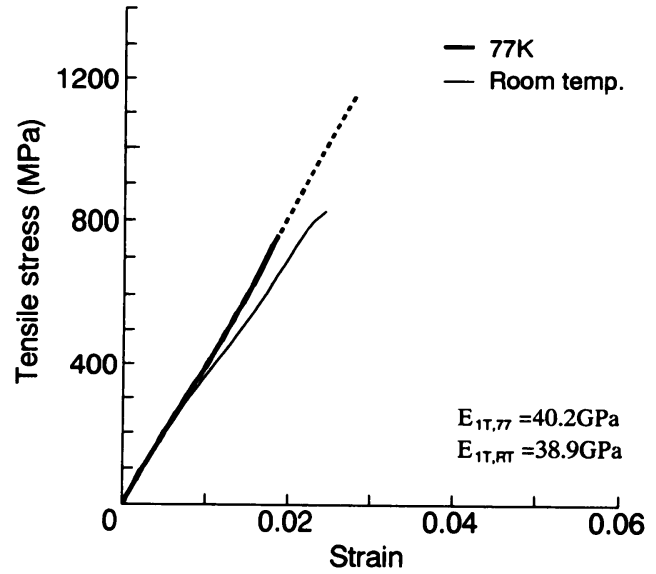

Fig. 5 Tensile stress-strain relation in the fiber direction for GFRP specimen at $77 \mathrm{~K}$ and at room temperature.

での一方向強化材の破断応力と弾性係数の值をそれぞれ 示す. 表の弾性係数の欄で括弧の中の值は, 破断直前の 応力とひずみより計算した値を参考のため示してある. これらの值は 1 本の試験片の実験結果である.

Fig. 5 に繊維方向に引張荷重を負荷したときの応力 とひずみの関係を示す，横軸はひずみで，縦軸は負荷荷 重と実験開始前の試験片断面積から計算した応力であ る. 太線が $77 \mathrm{~K}$ での実験値で, 細線が室温での実験值で ある. $77 \mathrm{~K}$ での実験では実験途中(約 $750 \mathrm{MPa}$ )でひず みゲージは切断され，ひずみの測定が不可能となったた め, ゲージ切断時の応力值と試験片破断時の応力値を破 線で結んで示している. 本実験の場合, 試験片破断まで ゲージによって測定できた例はなかった. $77 \mathrm{~K}$ と室温の 值を比較すると $77 \mathrm{~K}$ での值の方が線形性がよく, 負荷 開始からひずみゲージが切断される $750 \mathrm{MPa}$ までヤン グ率は $40.2 \mathrm{GPa}$ で一定とみなせる.一方, 室温でのヤ ング率は負荷開始で $38.9 \mathrm{GPa}$ だが, 破断瞬間の応力を ひずみで除した値は $33.7 \mathrm{GPa}$ となり，負荷開始のとき のヤング率と比較すると小さくなる.ポアソン比は $77 \mathrm{~K}$ では 0.31 で，室温では 0.32 であり両者に差はない.

破断応力は, $77 \mathrm{~K} て ゙ 1,150 \mathrm{MPa}$ であり, 室温での破 断応力 $899 \mathrm{MPa}$ と比較すると約 1.3 倍大きな值である. 試験片の破壊面は繊維断面および繊維に平行な断面であ る. 繊維の破断荷重よりも小さな荷重で樹脂や界面に微 小なき裂が生じ, これが繊維に平行に進展することによ り縦方向の破壊が生じている.

繊維方向圧縮のヤング率は, $77 \mathrm{~K}$ で $51.0 \mathrm{GPa}$ であ

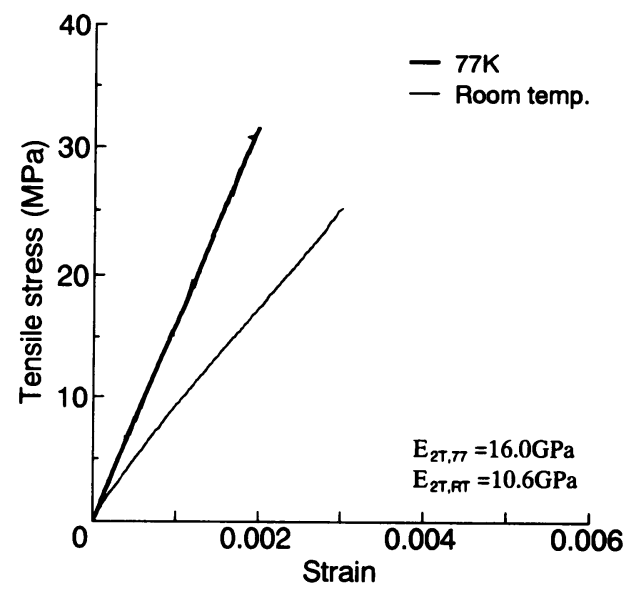

Fig. 6 Tensile stress-strain relation in the transverse direction for GFRP specimen at 77 $\mathrm{K}$ and at room temperature.

り，室温では $47.7 \mathrm{GPa}$ である．引張特性と同様にヤン グ率には温度による大きな差がない. 破断応力は $77 \mathrm{~K}$

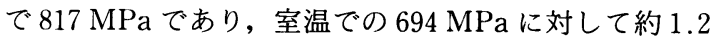
倍の大きさである。

\section{2 繊維に垂直方向の特性}

Fig. 6 に繊維に垂直方向へ引張荷重を負荷したとき の, 応力とひずみの関係を示す. 繊維に垂直方向の引張 弾性特性は, 室温においてはやや非線形性を示している が, $77 \mathrm{~K}$ ではほほ線形性を示している。ヤング率は, 室

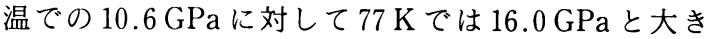
な差がある。この垂直方向のヤング率の向上はエポキシ の低温でのヤング率が大きく向上することに関係してい

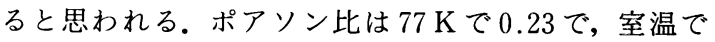
0.13 である. 繊維方向引張の場合ポアソン比に大きな 差はないが, 繊維と垂直方向引張では温度によりポアソ ン比が大きく変化する，この原因の 1 つとして, 低温で の繊維とマトリックスの接着性の変化が考えられるが, 詳細は今後検討する必要がある。

破断応力值は $77 \mathrm{~K} て ゙ 32.2 \mathrm{MPa}$ であり, 室温での $25.2 \mathrm{MPa}$ に対して約 1.3 倍の大きさである。これは 77 $\mathrm{K}$ におけるエポキシ樹脂の脆性化とともに, その強さも 向上しているとするとある程度説明できる. Fig. 7 に試 験片の破断面の走查型電顕写真を示す. 破断面は引張方 向に垂直な断面である。両温度において破断面では繊維 と樹脂の界面が観察され，室温よりも $77 \mathrm{~K}$ のほうが纎 維に付着している樹脂が大きい，破断面では，き裂が接 着界面を通って伝播していることがわかる。 

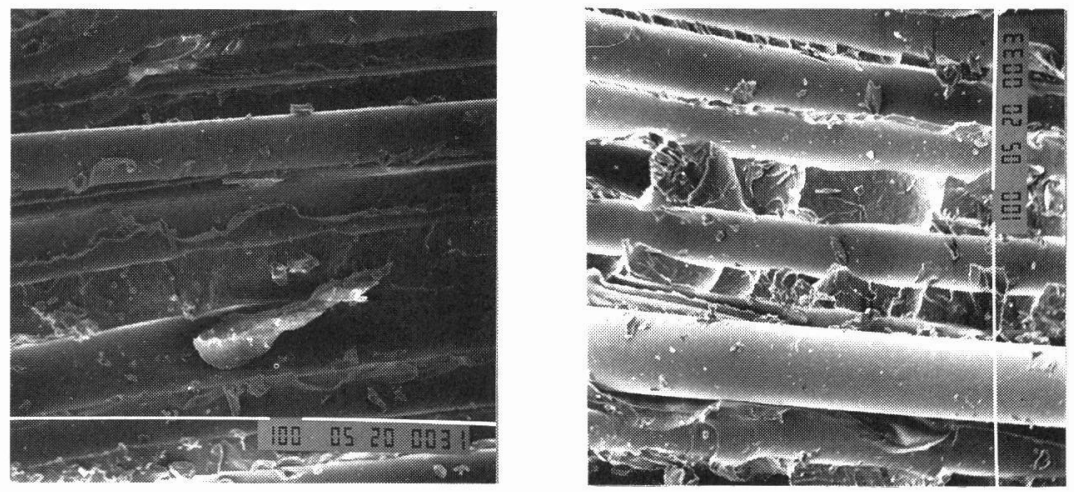

Fig. 7 Fracture surface of tensile test specimen in the transverse direction. Left : at $77 \mathrm{~K}$, Right : at room temperature.
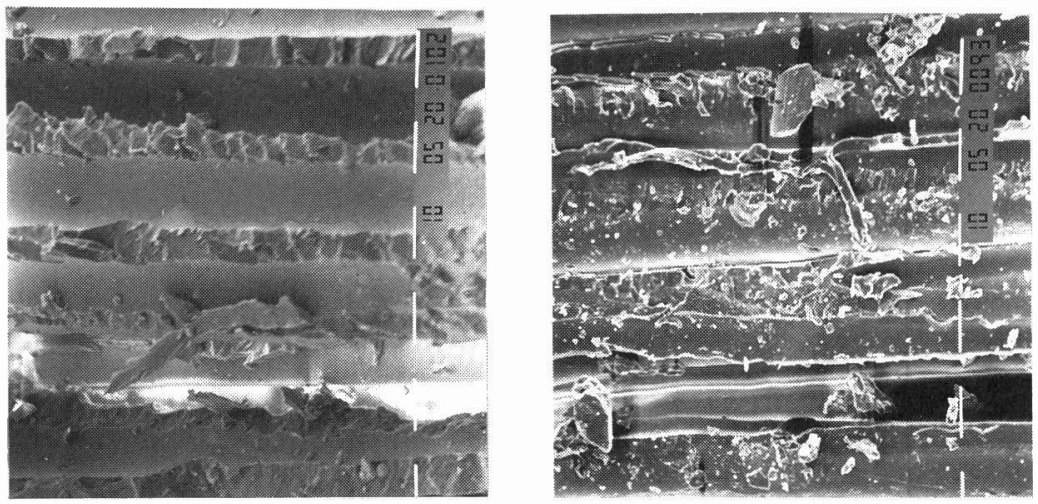

Fig. 8 Fracture surface of compressive test specimen in the transverse direction. Left : at $77 \mathrm{~K}$, Right : at room temperature.

引張変形特性と同様に, $77 \mathrm{~K}$ ではエポキシ樹脂の脆性 化に伴うヤング率の向上により, GFRP の圧縮のヤング 率も向上している。 $77 \mathrm{~K}$ におけるヤング率は $24.6 \mathrm{GPa}$ であり, 室温におけるヤング率 $14.7 \mathrm{GPa}$ の約 1.7 倍で ある。

温度の違いによる圧縮荷重に対する破断強さの変化は 顕著であり，室温での破断荷重が $98.0 \mathrm{MPa}$ であるのに 対して, $77 \mathrm{~K}$ では $235 \mathrm{MPa}$ と約 2.4 倍である。これは $77 \mathrm{~K}$ では工ポキシ樹脂の強さが大きくなることが寄与 していると考えられる. Fig. 8 に破断面の走査型電顕写 真を示す，破断面は繊維方向を含み，圧縮方向に対して ほぼ $45^{\circ}$ 傾いた面である。室温では破壊面に樹脂の塑性 変形が見られ, 凝集破壊の傾向が強い. 一方 $77 \mathrm{~K}$ では, 樹脂の塑性変形はなく繊維の抜けた溝がはっきりと見ら れ，界面破壞が生じている。

\section{3 纎維面内のせん断特性}

Fig. 9 に繊維面内で繊維に平行および垂直方向にせ

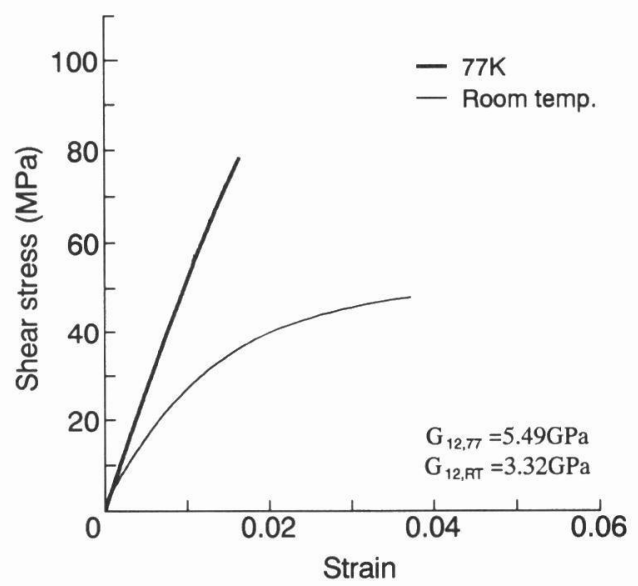

Fig. 9 Shear stress-strain relation for unidirectional GFRP specimen at $77 \mathrm{~K}$ and at room temperature. 
ん断荷重を負荷したときの，せん断応力とせん断ひずみ の関係を示す。応力はねじり荷重と実験開始前の試験片

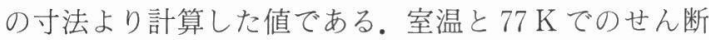
弾性特性の差は顕著である。室温では一般的な樹脂の特 性に似た非線形的な挙動を示しているが, $77 \mathrm{~K}$ では直線 的な挙動を示す. 室温では荷重の増大に対して樹脂が粘

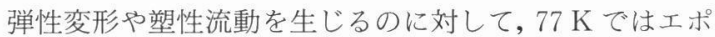
キシ樹脂が脆性的となり弾性特性が強くなるためであ る. $77 \mathrm{~K}$ での横弾性率は $5.49 \mathrm{GPa}$ であり, 室温での負 荷開始での横弾性率 $3.32 \mathrm{GPa}$ の約 1.7 倍である.また, $77 \mathrm{~K}$ での破断応力は $76.9 \mathrm{MPa}$ で, 室温での破断応力は $47.9 \mathrm{MPa}$ であり, $77 \mathrm{~K}$ では室温の約 1.6 倍である.

Fig. 10 に破断面の走査型電顕写真を示す. 破断面は
繊維に平行な断面である。室温では樹脂破断面は塑性変 形により大きく変形しているが, $77 \mathrm{~K}$ では樹脂は脆性的 に破壊を生じている.77 K および室温において, き裂は 繊維に影響を与えることなく樹脂や繊維樹脂界面にそっ て進展している。

\section{4. 対称斜交積層材の力学的特性}

\section{1 対称斜交積層円筒の引張負荷に対する応力ひず み曲線}

Fig. 11 から Fig. 13 に種々の積層角度をもつ対称斜 交積層円筒の $77 \mathrm{~K}$ と室温での応力ひずみ曲線を示す. 実線は実験值, 破線は Table 2 の基本物性值から積層理 論により計算した応力ひずみ曲線である。このときの破
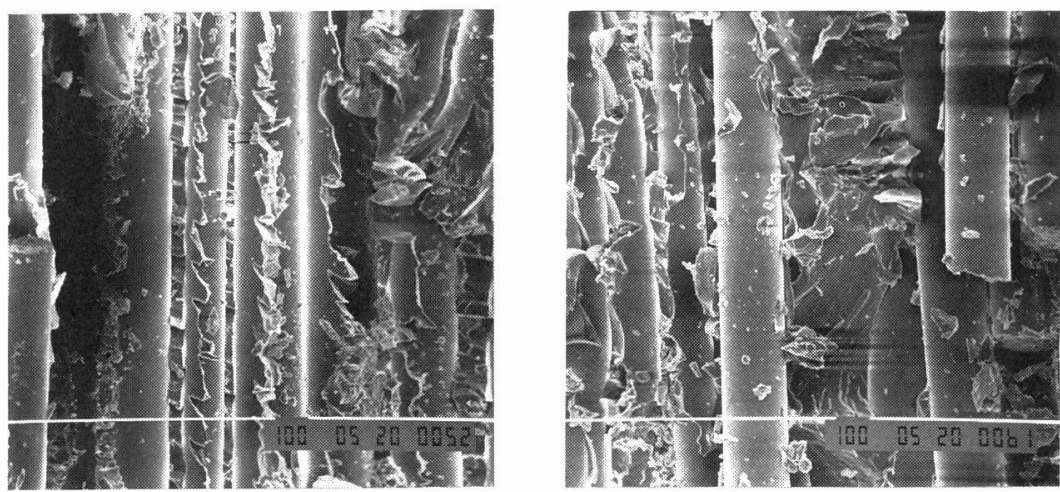

Fig. 10 Fracture surface of torsional test specimen. Left : at $77 \mathrm{~K}$, Right : at room temperature.

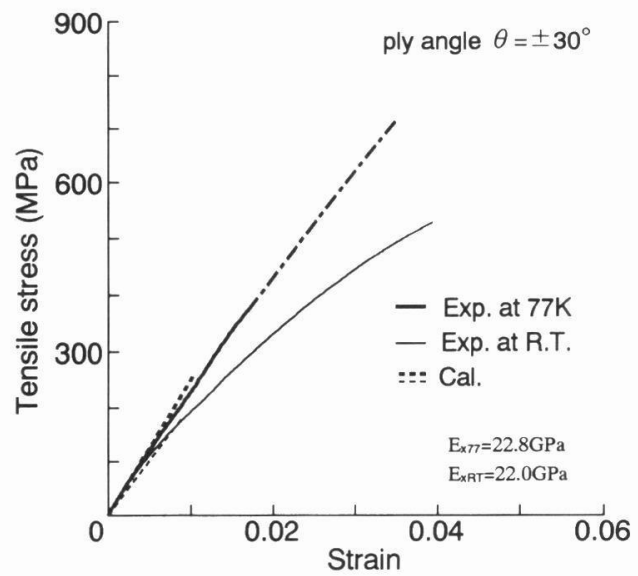

Fig. 11 Tensile stress-strain relation for laminated GFRP with angle ply at $77 \mathrm{~K}$ and at room temperature. ply angle $\theta=$ $\pm 30^{\circ}$.

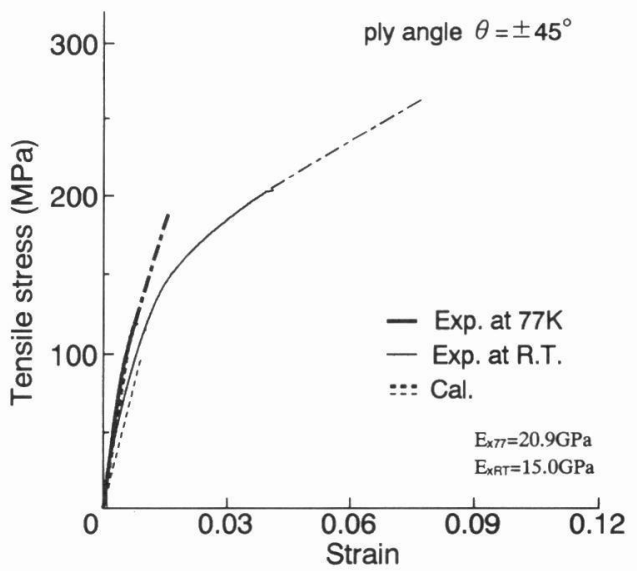

Fig. 12 Tensile stress-strain relation for laminated GFRP with angle ply at $77 \mathrm{~K}$ and at room temperature. ply angle $\theta= \pm$ $45^{\circ}$. 


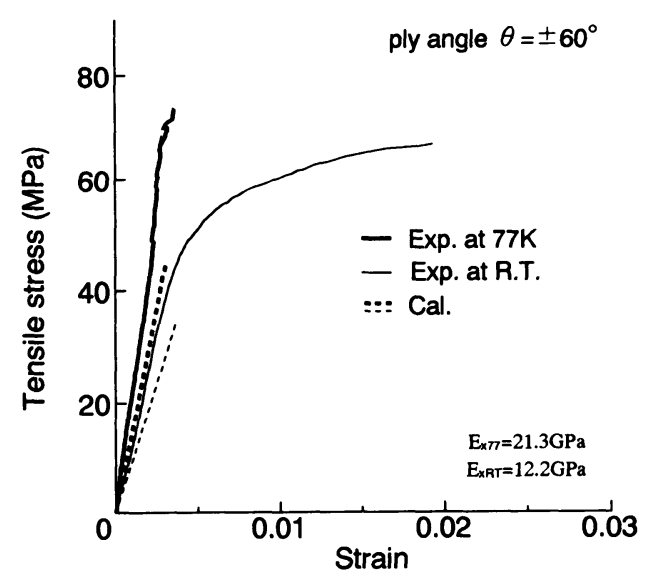

Fig. 13 Tensile stress-strain relation for lami. nated GFRP with angle ply at $77 \mathrm{~K}$ and at room temperature. ply angle $\theta=$ $\pm 60^{\circ}$.

断応力値は, Table 1 の基本破断応力値から最大応力説 により求めた。また実験途中にひずみゲージが切断され た応力点と, 試験片の破断応力を一点鎖線の直線で結ん である.

対称斜交積層円筒は負荷の小さいときは弾性変形を示 す。しかし，ある応力値を越えると，積層円筒内部での 局所的な破壊やマトリックスの非線形変形により, 応力 ひずみ曲線は非線形性を示す。この応力ひずみ曲線の非

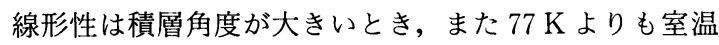
で顕著になる. $77 \mathrm{~K}$ では弾性限度を越えた後にひずみゲ ージが切断されるために, 弾性限度以上のひずみを計測 することは不可能であった。

\section{2 対称直交積層円筒のねじり負荷に対する応力ひ ずみ曲線}

Fig. 14 に対称直交積層円筒にねじり荷重を負荷した ときの $77 \mathrm{~K}$ と室温でのせん断応力とせん断ひずみの関 係を示す．比較のため一方向強化材のせん断特性の曲線 も示してある.両者はほほ同一の変形挙動を示している.

室温での実験では試験片の破断前に，断面形状が円形 から楕円形となるのでその負荷で実験を終えた。このと きのせん断ひずみは約 $9 \%$ あった。一方向強化材では 繊維に平行な方向に微小なき裂が生じると, 瞬時にこの き裂が進展して試験片を破断させる．しかし，対称直交 積層材では層間が接着されているために互いの層がき裂 の進展を妨げるため, 微小なき裂が発生してもそれがす ぐに試験片の破断に結び付くことはなく, 微小き裂は負 荷の増大にともない少しずつ進展していく.

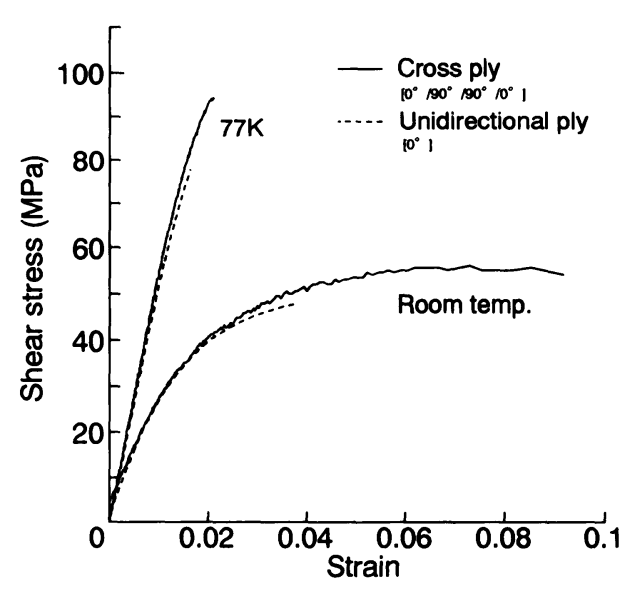

Fig. 14 Shear stress-strain relation for laminated GFRP with cross ply and unidirectional ply at $77 \mathrm{~K}$ and at room temperature.

Table 3 Fracture mode after tensile test of laminated GFRP with angle ply at 77 $\mathrm{K}$ and at room temperature.

\begin{tabular}{|c|c|c|}
\hline \multirow{2}{*}{ Ply angle } & \multicolumn{2}{|c|}{ Temp. } \\
\hline & $77 \mathrm{~K}$ & Room temp. \\
\hline $15^{\circ}$ & $\begin{array}{l}\text { Fiber failure with } \\
\text { delamination and } \\
\text { cracks in directions } \\
\text { parallel to fibers }\end{array}$ & Fiber failure \\
\hline $30^{\circ}$ & $\begin{array}{l}\text { Fiber failure with } \\
\text { delamination and } \\
\text { cracks in directions } \\
\text { parallel to fibers }\end{array}$ & Fiber failure \\
\hline $45^{\circ}$ & $\begin{array}{l}\text { Failure by } \\
\text { delamination and } \\
\text { cracks in } \\
\text { directions parallel } \\
\text { to fibers }\end{array}$ & Fiber failure \\
\hline $60^{\circ}$ & $\begin{array}{l}\text { Failure by cracks } \\
\text { in directions } \\
\text { parallel to fibers }\end{array}$ & $\begin{array}{l}\text { Failure by cracks } \\
\text { in directions } \\
\text { parallel to fibers }\end{array}$ \\
\hline
\end{tabular}

$77 \mathrm{~K}$ での実験では, 室温とは異なり, 層間破壊と緎維 に平行な方向のき裂により約 $95 \mathrm{MPa} て ゙$ 突然破断した. この破断は, 樹脂が脆性体となったため, せん断変形と 各層の繊維に平行なき裂の影響により層間での剝離が起 き，互いの層が他の層の繊維に平行なき裂の進展を妨げ 
ることができなくなり，き裂が急激に進展することによ り起きている.また， $77 \mathrm{~K}$ で対称直交積層円筒に層間破

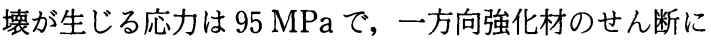
より繊維に平行なき裂を発生, 進展させうる応力 76.8 $\mathrm{MPa}$ に近い値となっている。

\section{3 対称斜交積層円筒の破壊様式と破断応力值}

Table 3 に種々の積層角度をもつ対称斜交積層円筒の 実験後の破壊の様子の特徵をまとめて示す。積層角度が $30^{\circ}$ の場合は, 室温と $77 \mathrm{~K}$ の両温度で積層角度 $15^{\circ}$ の場 合と同じ破壊様式である。積層角度が $45^{\circ}$ の場合は, 77 $\mathrm{K}$ では繊維の破断はなく, ゲージ部全体に層間剝離と積 層された各層で繊維に平行なき裂が生じている。これに 対して室温では, 一部で層間剝離が生じており, 剥離部 分と剝離してない部分の境界で応力集中により繊維が破 断している. 積層角度が $60^{\circ}$ の場合には室温と $77 \mathrm{~K}$ の両 温度で, 繊維に平行なき裂により, 試験片全体にらせん 状に破買が生じている。

Fig. 15 と Fig. 16 に室温と $77 \mathrm{~K}$ での, 対称斜交積層 円筒の積層角度と破断応力値の関係を示す. 実験值は白 丸が破壊が開始する応力であり, 黒丸は試験片が分離破 断する最終破断応力である. 破壊が開始する応力は各応 力ひずみ曲線が折れ曲がり始める応力值とし, 応力ひず み曲線の初期弾性線より $0.1 \%$ のずみで耐力法で定め た.また，一点鎖線は網目理論により求めた破断応力値 である.網目理論での計算では, Table 1 の瀻維方向の

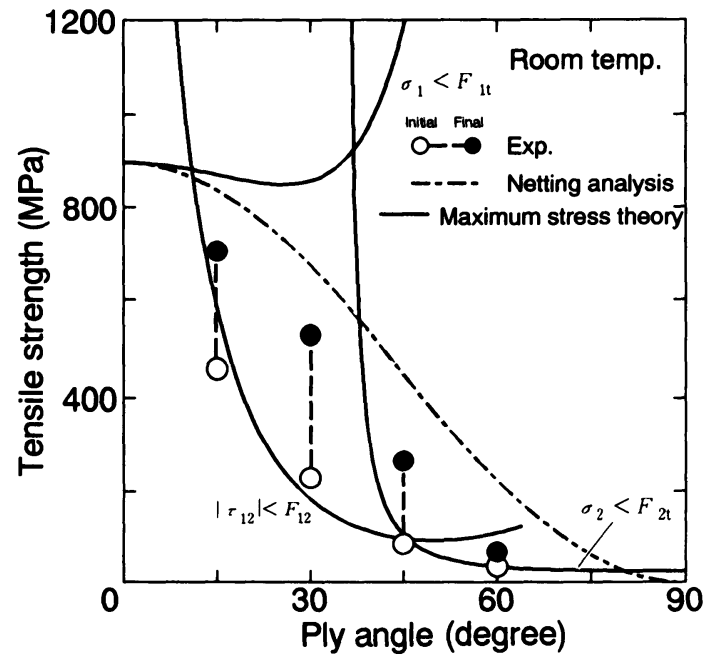

Fig. 15 Experimental and calculated failure stresses for laminated GFRP with angle ply at room temperature.
破断応力を繊維の強さと繊維の体積含有率の積とみなし て繊維の強さを計算した。実線は最大応力説により Table 1 の值を用いて計算した値である. 最大応力説に より示される 3 つの曲線は, 積層円筒の 1 つの層の主軸 座標系に関して繊維方向に生じる応力 $\sigma_{1}$, 繊維に垂直方 向に生じる応力 $\sigma_{2}$, 面内で生じるせん断応力 $\tau_{12}$ が, Table 1 に示したそれぞれの破断応力值に達する引張応 力を示している. 最大応力説では試験片に加わる応力 が, この3つの曲線の少なくとも 1 つを越えると破壊が 起こることを意味する.

実験値の破壊が開始する応力值は, 最大応力説により 計算した応力の曲線とほぼ一致している. 最大応力説で は，室温で積層角度が $15^{\circ} ， 30^{\circ}, 45^{\circ}$ の場合と $77 \mathrm{~K}$ で $15^{\circ}, 30^{\circ}$ の場合は, 面内せん断により破壊現象が開始す ることが示される.さらに実験後の試験片の観察からこ れらの試験片の最終破断は繊維で生じており，その破断 応力值は, 網目理論による計算值におおよそ従ってい る. $15^{\circ}$ の $77 \mathrm{~K}$ 以外は, 実験値が網目理論による計算值 よりも少し小さくなっているのは, 試験片内部の応力集 中部分で繊維が破断していることがその一因と考えられ る.また， $77 \mathrm{~K}$ では室温と比較して全ての基本的な負荷 に対する破断応力が大きくなるため, 積層角度が $45^{\circ}$ の 場合以外では, 積層角度が同じであれば $77 \mathrm{~K}$ での実験 值の方が室温での実験值よりも破壊が開始する応力およ び最終破断応力がともに大きな值となる．積層角度が

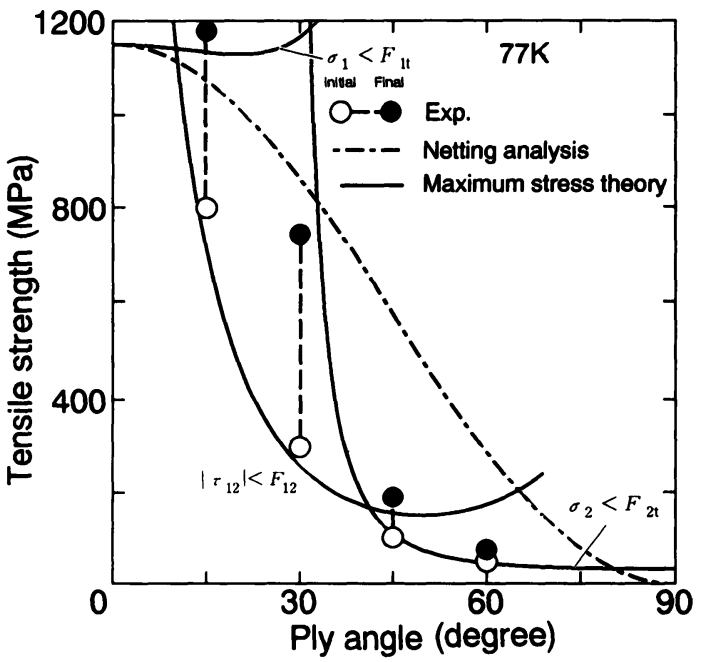

Fig. 16 Experimental and calculated failure stresses for laminated GFRP with angle ply at $77 \mathrm{~K}$. 
$45^{\circ}$ の場合には, 実験した中では唯一 $77 \mathrm{~K}$ での最終破断 応力値が室温での值よりも小さい.これは, 両温度にお ける破断様式の違いによるものである，室温では最終破 断は繊維の破断で生じるが, $77 \mathrm{~K} て ゙ は$ 緎維の破断応力値 に達するよりも小さな負荷で, 層間剥離と繊維に平行な き裂が試験片のつかみ部を除いた中央の平行部全体に生 じて荷重の伝達が不可能な状態となる，実験では最終的 な破断応力值は引張で約 $260 \mathrm{MPa}$ であり,これは繊維方 向を主軸とする座標系では約 $130 \mathrm{MPa}$ のせん断応力に 相当し, 対称直交積層円筒のねじり試験とほほ同じ破断 応力である。

\section{5. 結 論}

ガラス繊維強化エポキシ樹脂の一方向強化材と対称斜 交積層材の引張, 圧縮およびせん断の負荷実験を $77 \mathrm{~K}$ と室温において行った. 引張とせん断負荷実験は薄肉円 筒試験片を, 圧縮試験は板状試験片を用いて行った。

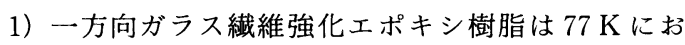
いて, 引張，圧縮およびせん断負荷に対して破断までほ ほ線形的な変形挙動を示す.

2) $77 \mathrm{~K}$ での一方向強化材の破断応力値は室温と比較 して, 引張, 圧縮およびねじりの負荷に対して大きくな る.

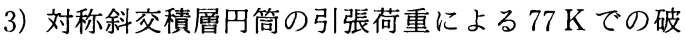
壊様式は, 層間剥離と繊維に平行なき裂を伴う破壊が生 じるが，斜交角度が大きくなると繊維に平行なき裂によ る破壊が支配的となる。

4）対称直交積層円筒にねじり荷重を負荷すると,室温 では非線形変形挙動を示すが, $77 \mathrm{~K}$ ではほぼ線形挙動を 示す.またその破壊様式は層間剝離と繊維に平行なき裂
による脆性的な破壊挙動を示す.

5）対称斜交積層円筒の引張負荷に対する強さは, 積

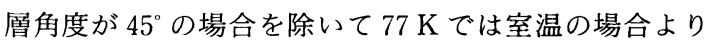
も大きくなる.

6）室温と $77 \mathrm{~K}$ の両温度において，対称斜交積層円筒 の引張負荷に対する破壊開始応力は最大応力説によりほ ぼ示され，最終破断が繊維の破断によるものは，その破 断応力値は網目理論によりほぼ示される.

本実験に用いた試料は，化成コンポジット社より提供 されたことを記し，同社に謝意を表します。

\section{参 考 文 献}

1) T. Nishiura, K. Katagiri, S. Owaki \& T. Okada : Cryogenics, 25 (1984), 329-333.

2）鷹合徹也，佐野一仁，福島英二：材料，37（1989）, 1185-1190.

3) A. Nyilas \& U. Jeske : Cryogenics, 28 (1988), 312-316.

4) G. Hartwig \& S. Knaak: Cryogenics, 25 (1984), 639-647.

5) K. Ahlborn: Cryogenics, 28 (1988), 267-272.

6) K. Ahlborn \& S. Knaak: Cryogenics, 28 (1988), 273-277.

7）駒井謙二郎, 箕島弘二, 石川直明：日本機械学会論 文集 (A 編)，59，566（1993），66-73。

8）鷹合徹也, 佐野一仁, 福島英二：材料, 38 (1990), 637-643.

9）前田利雄, 桜井昭男, 高島逸男, 山越寿夫 : 材料, 42 (1993), 239-243.

10）田中直敬, 白沢 洋, 新津 靖, 池上皓三 : 日本機 械学会論文集 (A 編)，57，543（1991），161-167. 